\title{
Life Prediction of Scraper Conveyor Based on Weibull Distribution Fault Diagnosis Theory
}

\author{
J. Yang, X.M. Ma, Z.S. Yang \\ School of Electrical and Control Engineering \\ Xi'an University of Science and Technology \\ Xi'an,China
}

\begin{abstract}
Weibull distribution life prediction theory is proposed for analyzing fault diagnosis of scraper conveyor in this paper. The scraper conveyor of coal mining mechanization is one of the important equipments in coal producing process, which may be damaged in the operation of the equipment malfunction or failure and its equipment life is very short. Therefore, the timely working state monitoring system of the scraper conveyor can effectively protect the equipment safe and reliable operation to prevent accidents. Simulation results show the life of scraper conveyor can be analyzed with Weibull distribution life prediction theory to reflect the distribution of the fault, and the fault condition is calculated to prolong the scraper conveyor life.
\end{abstract}

Keywords-life prediction; Weibull distribution; scraper conveyor; failure diagnostic

\section{INTRODUCTION}

Currently coal mine production, transport of downhole coal mining is mainly scraper conveyor. In practice, underground work environment and usage is very bad, from a security point of view, when the device has just put into operation, its security is very high, but after a certain period, the device due to fatigue, corrosion, wear, etc., safety will decline, there are some security risks will endanger the lives and safety of staff around the scraper conveyor. To eliminate these problems, extend equipment life, ensure the normal operation of equipment, improve the safety and reliability of the equipment, we should not only to strengthen the routine inspection and careful maintenance, but also research and summarize how to prevent accidents, which proposes life prediction theory scraper conveyor for fault diagnosis of the application.

\section{WEIBULL DISTRIBUTION}

Experiments show that the exponential distribution, normal distribution, Weibull distribution and lognormal distribution is major life distribution model of mechanical products[1]. Weibull distribution theory is a very broad application, has compatible with a variety of distribution models[2]. In this paper, the Weibull distribution model has been established to diagnose the failure of scraper conveyor.

The cumulative distribution function:

$$
F(t)=1-e^{-\frac{(t-\gamma)^{m}}{t_{0}}}
$$

Failure rate function is:

$$
\lambda(t)=\frac{m}{t_{0}}(t-\gamma)^{m-1}
$$

where: $m_{\text {is }}$ the shape parameter, $t_{0}$ is the scale parameter, $\gamma$ is the location parameter.

For the Weibull distribution, in practical work failure generally occurs after $t_{0}=\gamma$, no fault occurs before this moment. The study, failure usually occurs when the product is assumed that $\gamma=0$,then $\gamma=0, t_{0}=\eta^{m}$. Where, $\eta_{\text {is the }}$ scale parameter.

Available:

$$
F(t)=1-e^{-\frac{t^{m}}{\eta^{m}}} \quad \lambda(t)=\frac{m}{\eta^{m}} t^{m-1}
$$

Reliability function:

$$
R(t)=e^{-\frac{t^{m}}{\eta^{m}}}
$$

Average life expectancy:

$$
E(t)=\theta=\gamma+\eta \Gamma\left(1+\frac{1}{m}\right)
$$

Among them $\Gamma\left(1+\frac{1}{m}\right)$ is Gamma function

Reliable Life:

$$
t(R)=\gamma+\eta(-\operatorname{Ln} R)^{\frac{1}{m}}
$$

The median life expectancy: 


$$
t(0.5)=\gamma+\eta(\operatorname{Ln} 2)^{\frac{1}{m}}
$$

Characteristics of life:

$$
t\left(e^{-1}\right)=\gamma+\eta
$$

Use life:

$$
t(\lambda)=\gamma+\eta\left(\frac{\lambda \eta}{m}\right)^{\frac{1}{m}}
$$

Statistical analysis methods

Parametric statistical inference methods are generally two types, one is the chart analysis method, and the other is a numerical analysis. Parameter estimation method are many, three kinds of methods commonly are used in practice: interval parameter estimation, maximum likelihood estimation, regression analysis method. In this paper, the least squares parameter estimation was used.

Assume $n$ fault data, $\left(x_{1}, y_{1}\right),\left(x_{2}, y_{2}\right), \ldots$,
$\left(x_{n}, y_{n}\right)$ these data were profiled in the unit axes corresponding point, from a macro point of view, we can find these basically showing a straight line, then we say that $x$ and $y$ approximated as a linear function, that is $y=a x+b$, Where $a, b$ is undetermined constants. The method is called to determine the $a, b$ parameter, which is least squares method [3].

Least squares parameter estimation algorithm of Weibull method

For the two-parameter Weibull distribution reliable Life formula: $t(R)=10^{\mu+Z \rho \sigma}$, a linear transformation can be obtained:

$$
\begin{aligned}
& \ln \ln \frac{1}{1-F(t)}=-m \ln \eta+\ln t \\
& \mathrm{O} \rho \delta \varepsilon \rho^{y=\ln \ln \frac{1}{1-F(t)}} \\
& x=\ln t \\
& a=m
\end{aligned}
$$

$$
b=-m \ln \eta
$$

$F\left(t_{i}\right)$ according to the median rank approximation to seek, that is

$$
F\left(t_{i}\right) \approx \frac{i-0.3}{n+0.4}
$$

Which $i$ is a sequence number, $n$ is the total number of fault counts. $\left\{x_{i}, y_{i}\right\}_{i=1}^{n}$ can be obtained, using Matalab dose a least squares fit, we can get $a, b$, then $a, b$ are substituted into equation (13)(14), we can get $m 、 \eta$.

\section{LIFE PREDICTION}

Equipment life prediction refers to the device at a predetermined operating condition, which can be safely operated for how long. Generally speaking, life prediction mainly refers to the residual life prediction, also known as the residual life assessment evaluation. Life prediction is based on the life data of a large number of accumulation possess, analysis, field test, test, etc., the technology, called residual life prediction technology, hereinafter referred to as life prediction[4].Life Prediction intended to ensure safe operation of equipment to prevent catastrophic accidents and prolong life.

On the whole, life prediction methods can be divided into indirect and direct life prediction of two methods. Indirect life prediction methods namely stress analytical method, based on analysis the stress of component materials and material strength data, finite element method to calculate the component damage degree (common methods are: Robinson scores life loss estimates and function). Direct method is directly on the test sample after the experiment to obtain lifetime information (common methods are: the destruction of non-destructive test method and the experimental method). Difference between the two[5] is shown in Table 1. 
TABLE I. COMPARISON OF INDIRECT METHODS AND DIRECT METHODS LIFETIME

\begin{tabular}{|c|c|c|c|c|c|}
\hline \multicolumn{2}{|c|}{ project category } & \multirow{2}{*}{$\begin{array}{l}\text { practical } \\
\text { applicab } \\
\text { ility }\end{array}$} & \multirow{2}{*}{$\begin{array}{l}\begin{array}{c}\text { diagnos } \\
\text { tic } \\
\text { method } \\
\multicolumn{1}{c}{\mathbf{s}}\end{array} \\
\text { history } \\
\text { and } \\
\text { destructi } \\
\text { ve use } \\
\text { of } \\
\text { compon } \\
\text { ents } \\
\text { Criterio } \\
\text { n (linear } \\
\text { damage } \\
\text { rule, } \\
\text { etc.) }\end{array}$} & \multirow{2}{*}{\begin{tabular}{l}
\multicolumn{1}{c}{ monito } \\
\\
can \\
perform \\
on-line \\
monitor \\
ing
\end{tabular}} & \multirow{2}{*}{$\begin{array}{l}\begin{array}{c}\text { econo } \\
\text { my }\end{array} \\
\\
\\
\text { cost } \\
\text { time } \\
\text { and } \\
\text { money }\end{array}$} \\
\hline $\begin{array}{c}\text { Indir } \\
\text { ect } \\
\text { meth } \\
\text { ods }\end{array}$ & $\begin{array}{l}\text { stress } \\
\text { analysis } \\
\text { method }\end{array}$ & & & & \\
\hline \multirow[b]{2}{*}{$\begin{array}{c}\text { direct } \\
\text { meth } \\
\text { od }\end{array}$} & $\begin{array}{l}\text { destructive } \\
\text { test } \\
\text { method }\end{array}$ & $\begin{array}{ll}\text { can cut } \\
\text { parts } \\
\text { style }\end{array}$ & $\begin{array}{l}\text { use of } \\
\text { destructi } \\
\text { ve } \\
\text { testing }\end{array}$ & $\begin{array}{l}\text { should } \\
\text { not be } \\
\text { used }\end{array}$ & $\begin{array}{l}\text { cost } \\
\text { time } \\
\text { and } \\
\text { money }\end{array}$ \\
\hline & $\begin{array}{l}\text { non-destru } \\
\text { ctive test } \\
\text { method }\end{array}$ & $\begin{array}{l}\text { can not } \\
\text { apply } \\
\text { when cut } \\
\text { style:(1) } \\
\text { diagnosis } \\
\text { of a } \\
\text { restricted } \\
\text { portion } \\
(2) \quad a \\
\text { narrow } \\
\text { space }\end{array}$ & $\begin{array}{l}\text { damage } \\
\text { control } \\
\text { test } \\
\text { using a } \\
\text { standard } \\
\text { curve }\end{array}$ & $\begin{array}{l}\text { can } \\
\text { regularl } \\
\mathrm{y}\end{array}$ & $\begin{array}{l}\text { save } \\
\text { time } \\
\text { and } \\
\text { money }\end{array}$ \\
\hline
\end{tabular}

From table 1, the limitations of the two methods can be seen. The level of quality of any equipment is measured by Technical parameters and indicators, but regardless of which device has a common quality indicator, namely the use of reliability. Life assessment and failure analysis of equipment which based on reliability life prediction, combined with the operation of equipment on-line monitoring and diagnostic technology that can more accurately grasp its operating status, the extent of loss of life come to the device, and then determine the best maintenance on equipment the opportunity to achieve the status of maintenance, to ensure the safe operation of equipment and improve its operating conditions. Life is the main object of study the product reliability, the reliability of the products is also an important indicator, the life of the product is usually a continuous random variable[6], because of the failure mechanism is different, there are different life distribution.

\section{SCRAPER CONVEYOR}

Scraper conveyer common faults[7]have motor can't start, the motor and the end of the shaft portion of fever, abnormal motor sound pressure couplers slipping, one of the oil pressure is too high coupling, reducer does not sound normal, reducer high oil temperature or oil spills, scraper teeth or even jump off the chain on the sprockets, scraper groove, middle groove connecting pin drop, telescopic hydraulic cylinder piston rod is not working or does not move. This article is the fault of the motor.

Screening and organizing fault data, and then analyses reliability life prediction research. Matlab software for numerical computation and image processing with a very powerful function and easy to operate, easy to start[8]. Based on previous experience with Weibull distribution the compatibility of this characteristic[9], scraper conveyor reliability life distribution, to analyze its revalidation. Scraper conveyor fault data collection reacts to the reliability life analysis of the scraper conveyor which is important, it is not only the basis of using mathematical statistics and hypothesis test, but also the basis of scraper conveyor reliability life model, so science and sufficient raw data is very important [10-11]. Table 2 is a scraper conveyor motor trouble-free working hours.

TABLE II. FAILURE STATISTICS OF SHEN NiNG GSZ764 / 630-TYPE SCRAPER CONVEYOR MOTOR

\begin{tabular}{|c|c|}
\hline device name & running time/min \\
\hline $\begin{array}{l}\text { GSZ764 / } \\
\text { 630-type } \\
\text { scraper } \\
\text { conveyor }\end{array}$ & $\begin{array}{l}2875,4230,4280,4280,6010,7205,10045,1 \\
8730,27370,30115,37400,48975\end{array}$ \\
\hline
\end{tabular}

Fault data directly using the approximate median rank formula to calculate, results such as table 3 , and then according to the principle of least squares fitting.

TABLE III. ThE APPRoXimation MEdian RANK Formula CALCUlate RESULTS

\begin{tabular}{|l|l|l|l|}
\hline No. $i$ & \multicolumn{1}{|c|}{$\begin{array}{c}\text { running } \\
\text { time/min }\end{array}$} & $\boldsymbol{X}_{i}$ & $\boldsymbol{Y}_{i}$ \\
\hline $\mathbf{1}$ & 2875 & 7.96 & -2.8456 \\
\hline $\mathbf{2}$ & 4230 & 8.35 & -1.9139 \\
\hline $\mathbf{3}$ & 4280 & 8.36 & -1.4041 \\
\hline $\mathbf{4}$ & 4480 & 8.41 & -1.0373 \\
\hline $\mathbf{5}$ & 6010 & 8.70 & -0.7413 \\
\hline $\mathbf{6}$ & 7205 & 8.89 & -0.4852 \\
\hline $\mathbf{7}$ & 10045 & 9.21 & -0.2521 \\
\hline $\mathbf{8}$ & 18730 & 9.84 & -0.0304 \\
\hline $\mathbf{9}$ & 27370 & 10.22 & 0.1901 \\
\hline $\mathbf{1 0}$ & 30115 & 10.31 & 0.4216 \\
\hline $\mathbf{1 1}$ & 37400 & 10.53 & 0.6867 \\
\hline $\mathbf{1 2}$ & 48975 & 10.80 & 1.0558 \\
\hline
\end{tabular}

Method of least squares equation (15)can be calculated by $y_{i}$. Matalab least squares method combined with the availability of $a=1.0657, b=-10.4391$,fitting graphic in Fig. 1:

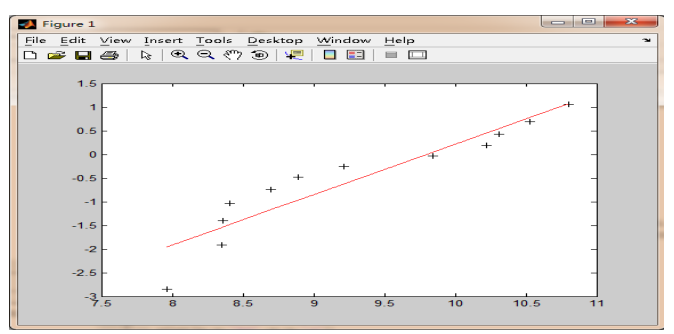

FIGURE I. CURVE FITTING

According to the formula

(13) 
there: $m=a=1.0657$

$$
\eta=\exp \left(-\frac{b}{a}\right)=17952.7754
$$

So the failure distribution function:

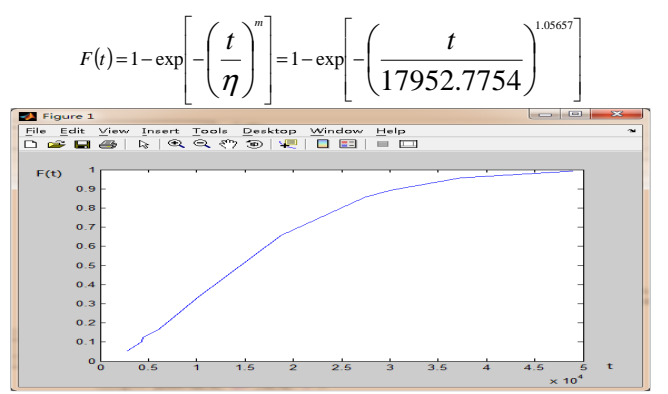

FIGURE II. FAILURE CUMULATIVE DISTRIBUTION FUNCTION CURVES

Fig.2 shows the failure cumulative distribution.

Reliability function: $R(t)=e^{-\left(\frac{t}{17952.7754}\right)^{1.0657}}$

Failure rate: $\lambda(t)=\frac{1.0651}{17952.7754^{1.0651}} t^{1.0651}$

MTBF: $E(t)=\eta \Gamma\left(1+\frac{1}{m}\right)=17523.7$

Reliable Life: $t(0.9)==2173.5279$

The median life expectancy: $t(0.5)=12726.7225$

Characteristics of life: $t\left(e^{-1}\right)=17857.6257$

Reliability: when the running time of the scraper conveyor to the 12th fault reliability for $48975 \mathrm{~min}$

$$
R(t)=e^{-\left(\frac{t}{17952.7754}\right)^{1.0657}}=0.0543
$$

Obtained by calculating the reliability, can be seen scraper conveyor motor running when $48975 \mathrm{~min}$, low reliability, security is poor, much-needed downtime for maintenance or scrapped.

\section{V.SUMMARY}

This article focuses on the application of life theory to scraper conveyor fault diagnostic analysis. Due to time constraints, the condition of the scraper conveyor fault data collection is not comprehensive enough, so its analysis has some limitations. Some practical factors in the analysis do not take into account, the actual remains to be tested. Other parts of the scraper conveyor is carried out a lot of data statistics, analysis the law of their life, a comprehensive summary for the life and failure law of the scraper conveyor then for the users to find maintenance time of scraper conveyor, thereby improving reliability life of the scraper conveyor and enterprises economic efficiency .

\section{REFERENCES}

[1] Xue Zhen. High-speed stamping system reliability study [D] Xi'an: Chang'an University, 2008.

[2] You Dazhang. Fatigue reliability of the least squares method in the Weibull distribution[J] Journal of hubei university of technology, 2009

[3] Gao Shesheng,Zhang Lingxia. Reliability Theory and Engineering Applications [M] Beijing: National Defense Industry Press, 2002.08.

[4] Li Jun, Jin Jiashan, Yu Jun. J. Li, J.S. Jin, J. Yu. Consider mechanical equipment remaining life model of repair influence $[\mathrm{J}]$, Chinese ship repair, 2004, (2): 37-39.

[5] [5]Zhou Jinhui, Shi Hu-li. Major equipment testing and life prediction method study [D], Xi'an: Xi'an University of Electronic Science and Technology, 2006.

[6] Zou Hui, Huag Xiao. Based on large CNC milling tooth machine reliability evaluation of two weibull distribution $[\mathrm{J}]$. Mechanical design and manufacturing, 2010 (2) 198-200.

[7] Li Ji. Mining equipment performance measurement and state diagnostic techniques [M], Beijing, Coal Industry Press.

[8] Ma Li .MATLAB mathematical experiments and modeling [M], Beijing: Tsinghua University Press, 2010.

[9] Yu Xiaohong, Zhang Laibin. Based on the new Weibull distribution parameter estimation method for equipment life of reliability analysis [J], Mechanical strength, 2007, 29 (6): 932-936.

[10] He Guofang. Reliability data collection and analysis [M], Beijing: National Defense Industry Press, 1995.

[11] Yang Jing. Electromechanical Product Reliability and Life Data Analysis [D], Harbin Polytechnic University, 2005 